\title{
A posição dos professores sobre o Ensino Religioso numa escola pública de Ensino Fundamental em Pinheiro-MA ${ }^{1}$
}

\section{Teachers' position on Religious Education in a public school in Pinheiro- MA}

\author{
JACIMARA SARGES ABREU \\ Mestra em Ciências Sociais \\ jacisabreu@gmail.com
}

\section{JOSÉ BENEVIDES QUEIROZ}

Doutor em Ciências Sociais

Professor do Dep. de Sociologia e Antropologia e do Programa de Pós-graduação em Ciências Sociais da UFMA jose.benevides@ufma.br

\section{RESUMO}

Este artigo aborda o tema Ensino Religioso na educação pública brasileira. Tem-se como objetivo descrever o posicionamento dos professores sobre a presença do Ensino Religioso na Escola Pública Municipal Pesquisada (EPMP), em Pinheiro, município do estado do Maranhão. Para isso, optou-se pelo estudo de caso, como procedimento metodológico de pesquisa, e as entrevistas, como instrumento para a coleta de dados. Ressalta-se que, dos 14 professores da EPMP, definidos para as entrevistas, apenas 11 responderam às questões. A partir dos dados coletados, constatou-se que as posições dos professores sobre o Ensino Religioso na escola pública de Ensino Fundamental não são baseadas no princípio da laicidade, da diversidade, da pluralidade de ideias, de opiniões, de crenças. As visões são "limitadas" e controversas, bem como transgridem as leis, as resoluções e os documentos normativos que fundamentam o Ensino Religioso.

Palavras-chave: Ensino Religioso. Educação. Laicidade. Escolas.

\begin{abstract}
This article tackles the theme of Religious Education in Brazilian public education. It have to describe the position of teachers on the presence of Religious Education in the Municipal Public Researched School (EPMP), in Pinheiro, a municipality in the state of Maranhão. For the analysis of this municipal public school, opted for it case study, as a methodological research procedure and, the interviews, as an instrument for the collection of dates. Stand out that, of the 14 teachers of the EPMP, defined for the interviews, only 11 answered the questions. From of the dates collected, the research found that teachers' positions on Religious Education in the public school are not based on the principle of secularity, diversity, plurality of ideas, opinions, beliefs. The views are "limited" and controversial, as well as violating laws, resolutions and normative documents, which substantiate Religious Education.
\end{abstract}

Keywords: Religious Education. Education. Secularity. Schools.

\footnotetext{
${ }^{1}$ Artigo recebido em 30/10/2020 e aprovado em 10/03/2021.
} 
Rev. Interd. em Cult. e Soc. (RICS), São Luís, v. 7, n. 1, p. 127 - 147, jan./jun. 2021

ISSN eletrônico: 2447-6498

\title{
1 INTRODUÇÃO
}

Este artigo aborda o tema Ensino Religioso na educação pública brasileira. Tem-se como objeto de estudo os professores da Escola Pública Municipal Pesquisada (EPMP) ${ }^{2}$, do município de Pinheiro, estado do Maranhão. Especificamente, objetiva-se descrever o posicionamento dos professores sobre a presença do Ensino Religioso na escola pública de Ensino Fundamental, em Pinheiro, onde exercem sua prática pedagógica.

Para a construção desse objeto, considerou-se as vivências de algumas situações, em 2019, como professora contratada do Ensino Fundamental - Anos Finais (6. ao 9. ${ }^{\circ}$ ano), numa escola pública municipal, onde as crenças e as práticas religiosas católicas, incorporadas nas aulas de Ensino Religioso, eram frequentes e as aulas com um conteúdo de caráter mais laico não eram vistas com "bons olhos" em razão de contrariar as estratégias de ensino "consagradas" e "inquestionáveis" naquele ambiente escolar, constituído por um corpo docente de efetivos e com longa experiência no magistério em instituição regular de Educação Básica.

Para quem estava iniciando a vida docente e recém-formada, essas posições eram vistas como bem "conflitantes", "controversas" e "embaraçosas" de se presenciar numa escola pública, considerando a questão da laicidade do Estado e, por consequência, do ensino público brasileiro, estabelecida com a Constituição de 1891. Por laicidade, tem-se como referência o conceito definido assim por Mariano (2011, p. 244):

\begin{abstract}
Refere-se, histórica e normativamente, à emancipação do Estado e do ensino público dos poderes eclesiásticos e de toda referência e legitimação religiosa, à neutralidade confessional das instituições políticas e estatais, à autonomia dos poderes político e religioso, à neutralidade do Estado em matéria religiosa (ou a concessão de tratamento estatal isonômico às diferentes agremiações religiosas), à tolerância religiosa e às liberdades de consciência, de religião (incluindo a de escolher não ter religião) e de culto. (grifo nosso).
\end{abstract}

As situações vivenciadas, como professora contratada, serviram como ponto de partida na escolha e na formulação deste problema de pesquisa: qual a posição dos professores sobre a presença do Ensino Religioso na escola pública de Ensino Fundamental - onde exercem sua prática pedagógica -, tendo em vista o princípio de laicidade que rege o ensino público

\footnotetext{
${ }^{2}$ Por questões de caráter ético, não serão mencionados os nomes da escola e dos professores pesquisados. Durante todo o texto, a instituição foi identificada por Escola Pública Municipal Pesquisada - EPMP, e os professores por letras maiúsculas, por exemplo, Professor A, Professor B, etc.
} 
Rev. Interd. em Cult. e Soc. (RICS), São Luís, v. 7, n. 1, p. 127 - 147, jan./jun. 2021 ISSN eletrônico: 2447-6498

brasileiro? Partiu-se da hipótese de que os professores se posicionam com argumentos amparados em suas convicções pessoais e confissões religiosas, que transgridem as leis, as resoluções e os documentos normativos, que fundamentam o Ensino Religioso nas escolas públicas do país.

Sendo assim, a partir do objetivo principal, que é analisar a posição dos professores sobre a presença do Ensino Religioso numa escola pública de Ensino Fundamental, em Pinheiro, tendo em vista o princípio de laicidade que rege o ensino público brasileiro, foram estabelecidos os seguintes objetivos específicos: 1) discutir sobre oferta e obrigatoriedade do Ensino Religioso na escola; 2) analisar a situação do Ensino Religioso na grade curricular; 3) e identificar outras formas de presença religiosa na escola (símbolos religiosos, por exemplo).

Além disso, é oportuno lembrar a relevância científica deste artigo à medida que busca contribuir com os estudos e as pesquisas que discutem a relação entre religião e educação no Brasil e no Maranhão, já que analisa a posição dos professores sobre o Ensino Religioso numa escola pública de Ensino Fundamental em Pinheiro. Outro aspecto que se pode ressaltar é a possibilidade do presente trabalho ser utilizado como uma nova referência de estudo nessa cidade, assim como abrir outras perspectivas e ideias de pesquisas, visto que não foi encontrada nenhuma outra com esse mesmo objeto.

Assim, além da introdução e das considerações finais, o trabalho está estruturado em outras duas partes. No tópico metodologia fala-se sobre os procedimentos metodológicos de pesquisa e os instrumentos utilizados para a coleta de dados. No tópico resultados e discussão, foram analisadas as informações colhidas durante a pesquisa, especificamente as questões relacionadas à obrigatoriedade do Ensino Religioso na EPMP e à situação do Ensino Religioso na grade curricular, bem como as outras formas de presença religiosa na escola.

\section{METODOLOGIA}

Os dados do Instituto Brasileiro de Geografia e Estatística (2019) mostram que a população estimada em Pinheiro, em 2020, é de 83. 777 habitantes, divididos entre pessoas das zonas rural e urbana. Pinheiro é o maior município, em termos populacionais, entre os 21 municípios que compõem a Baixada Maranhense. Além da cidade ser considerada um centro regional, onde as populações das cidades vizinhas se deslocam em busca de prestação de serviços, empregos, etc., ela também segue de perto alguns traços dos fenômenos religiosos no Brasil. Pinheiro, por exemplo, tem presença católica majoritária, que é visível pelos templos estarem estabelecidos nos espaços públicos privilegiados e, ainda, ter um feriado 
Rev. Interd. em Cult. e Soc. (RICS), São Luís, v. 7, n. 1, p. 127 - 147, jan./jun. 2021 ISSN eletrônico: 2447-6498

municipal em homenagem ao padroeiro Santo Inácio de Loyola, que é uma referência ao protagonismo do catolicismo na cidade.

A pesquisa foi realizada na rede municipal de ensino em Pinheiro, que possui 1.480 professores, dentre os quais 590 contratados e 890 efetivos. Ao todo, contabiliza-se também 139 estabelecimentos públicos direcionados às etapas da Educação Infantil e do Ensino Fundamental, que são divididos em 13 polos: Sede, Vila Filuca, Pacas I, Pacas II, Fortaleza, Porão Grande, Santo Antônio dos Carvalhos, São Caetano, Polo Paraíso, Polo Pirinã, Polo Santa Vitória, Polo Bom Viver e Polo Campo Novo; informa-se que cada polo agrega cerca de dez escolas.

O estudo priorizou os professores somente de uma dessas escolas, localizada na zona rural, a $15 \mathrm{~km}$ de distância da zona urbana, e que se vincula ao Polo Bom Viver. A EPMP tem 14 professores, entre efetivos e contratados. É uma escola dedicada à Educação Infantil e ao Ensino Fundamental, que funciona em dois turnos: manhã e tarde, tem cinco salas de aulas, uma sala dividida entre direção e secretaria, uma sala de professores (que funciona como biblioteca), uma quadra de esportes (descoberta e sem manutenção), dois banheiros, uma cozinha repartida com despensa e almoxarifado, dois corredores e um pátio. Quanto aos equipamentos de apoio, dispõe de uma caixa amplificada, uma impressora e um computador.

Para a análise dessa escola pública municipal, optou-se pelo estudo de caso, como procedimento metodológico de pesquisa, que além de ser caracterizado como um estudo de uma instituição, um sistema educativo, uma pessoa e uma unidade social, é uma investigação que busca conhecer em profundidade, isto é, que se debruça sobre uma situação específica que se supõe ser única em muitos aspectos, procurando descobrir o que há nela de mais essencial e característico. Melhor dizendo, o fato de ter sido selecionado somente os professores de uma única escola da rede municipal de ensino, foi para coletar informações significativas. (FONSECA, 2002; SILVEIRA; CÓRDOVA, 2009).

A intenção com esse procedimento metodológico de pesquisa foi revelar como os docentes se posicionam sobre o Ensino Religioso numa escola pública de Ensino Fundamental, em Pinheiro. Para isso, utilizou-se ainda a entrevista que, segundo Gil (2008, p. 109), pode ser definida:

[...] como uma técnica em que o investigador se apresenta frente ao investigado e lhe formula perguntas, com o objetivo de obtenção de dados que interessam à investigação. A entrevista é, portanto, uma forma de interação social. Mais especificamente, é uma forma de diálogo assimétrico, em que uma das partes busca coletar dados e a outra se apresenta como fonte de informação. 
Rev. Interd. em Cult. e Soc. (RICS), São Luís, v. 7, n. 1, p. 127 - 147, jan./jun. 2021 ISSN eletrônico: 2447-6498

Durante a interação entre investigadores e investigados, adotou-se a entrevista estruturada. Esse tipo de entrevista, foi utilizado para coletar dados de forma padronizada e em condições iguais; os entrevistados responderam as mesmas perguntas e receberam as mesmas explicações (FONSECA, 2002).

Ressalta-se que foram definidos os 14 professores da EPMP para as entrevistas, obtendo-se resposta de 11 destes docentes às questões. Eles demostraram maior disposição e interesse na realização das entrevistas. Inclusive, os três professores que se negaram a responder as perguntas eram efetivos e católicos. Com relação ao perfil dos 11 investigados, o Quadro 1 apresenta informações relativas à idade, anos de magistério, área de formação e confissão religiosa. Eis o quadro:

Quadro 1 - Idade, anos de magistério, área de formação e confissão religiosa

\begin{tabular}{|c|c|c|c|c|}
\hline \multicolumn{5}{|c|}{ PERFIL DOS PROFESSORES ENTREVISTADOS } \\
\hline IDENTIFICAÇÃO & IDADE & ANOS DE MAGISTÉRIO & ÁREA DE FORMAÇÃO & CONFISSÃO RELIGIOSA \\
\hline Professor A & 40 a 49 anos & Mais de 20 anos & Ciências Biológicas & Católico \\
\hline Professor B & 40 a 49 anos & 11 a 15 anos. & Pedagogia & Evangélico \\
\hline Professor C & 30 a 39 anos & 16 a 20 anos & Ciências Biológicas & Católico \\
\hline Professor D & 30 a 39 anos & 16 a 20 anos & Pedagogia e Matemática & Católico \\
\hline Professor $\mathrm{E}$ & Mais 60 anos & Mais de 20 anos & História & Católico \\
\hline Professor $\mathrm{F}$ & 50 a 59 anos & Mais de 20 anos & Letras & Católico \\
\hline Professor G & 40 a 49 anos & 11 a 15 anos. & Pedagogia & Evangélico \\
\hline Professor $\mathrm{H}$ & 40 a 49 anos & 16 a 20 anos. & Geografia & Católico \\
\hline Professor I & 20 a 29 anos & 1 a 5 anos. & História & Evangélico \\
\hline Professor J & 40 a 49 anos & Mais de 20 anos & Letras & Católico \\
\hline Professor K & 40 a 49 anos & 6 a 10 anos. & Magistério & Católico \\
\hline
\end{tabular}

Fonte: Dados da pesquisa

De modo geral, verifica-se que a maioria dos entrevistados é católica, com idade entre 40 a 49 anos e mais de 20 anos no magistério em instituição regular de Educação Básica. Com a autorização dos entrevistados, todos os relatos foram gravados e, depois, transcritos e revisados. Inclusive, nos depoimentos mencionados, neste texto, não se manteve a fidedignidade dos erros e vícios de linguagem dos investigados.

Assim, com as entrevistas realizadas na EPMP, obteve-se um "conjunto de respostas" que, para analisar e interpretá-lo, foi necessário ordenar e organizá-lo, como recomenda Fonseca (2003). Nesse sentido, pensa-se que os dados coletados, podem relevar as posições dos professores sobre a presença do Ensino Religioso na escola pública de Ensino 
Rev. Interd. em Cult. e Soc. (RICS), São Luís, v. 7, n. 1, p. 127 - 147, jan./jun. 2021

ISSN eletrônico: 2447-6498

Fundamental — onde exercem sua prática pedagógica, já que foram as principais "fontes de informação" desta pesquisa.

\title{
3 RESULTADOS E DISCUSSÃO
}

As pesquisas e os debates sobre a presença do Ensino Religioso nas escolas públicas brasileiras foram suscitados com instauração da República, um regime político que se inaugurou e efetivou a separação entre Igreja e Estado com a promulgação da Constituição de 1891 (GIUMBELLI, 2014). Com essa lei, o catolicismo perdeu o estatuto de religião oficial do Brasil, isto é, o aparato que lhe garantiu reprodução e exclusividade no Período Colonial (1500 - 1822) e no Período Imperial (1822 - 1889) (STEIL, 2011; ORO, 2011).

Com a laicidade das instituições públicas, o Ensino Religioso foi negado pela Constituição de 1891, mas foi permitido na Constituição de 1934 e, também, continuou na atual Constituição Federal, que entrou em vigor em 1988. Sobre isso, Giumbelli (2008, n.p., grifo nosso) explica que:

\begin{abstract}
A permanência do ensino religioso como disciplina regular nas escolas públicas tem como principal base jurídica a Constituição de 1988, que não faz senão ratificar as disposições que ganharam vigência, no plano constitucional, desde 1934. Apesar da denominação genérica, o ensino religioso, na maior parte do país, foi campo de atuação quase exclusivo da Igreja Católica, que se estruturou para tanto. Coube-lhe a liderança nos esforços que mantiveram o ensino religioso na Constituição de 1988. Curiosamente, isso ocorre exatamente quando o catolicismo perde adeptos e espaço na sociedade brasileira.
\end{abstract}

Assim, como o Estado passou a ser oficialmente laico, o Ensino Religioso nas escolas públicas seria uma "[...] forma de retomada da presença religiosa na esfera pública" (CAMURÇA, 2017, p. 869), pois "[...] a não existência de Ensino Religioso significaria a ausência do religioso na escola" (GIUMBELLI, 2008, n.p.), sobretudo a perda da influência católica na sociedade.

Nos termos da Constituição Federal de 1988 (art. 210, parágrafo 1) e da Lei de Diretrizes e Bases (art. 33, 1996 alterado pela Lei n. 9 475/1997), o Ensino Religioso, de matrícula facultativa, é obrigatório apenas na etapa do Ensino Fundamental das escolas públicas do país, sem proselitismo.

Na Base Nacional Comum Curricular, o Ensino Fundamental é organizado e tratado em duas fases de escolarização: Ensino Fundamental - Anos Iniciais ( $1^{\circ}$ ao $5^{\circ}$ ano) e Ensino Fundamental - Anos Finais ( $6^{\circ}$ ao $9^{\circ}$ ano). Trata-se da etapa mais longa da Educação Básica que, durante nove anos, atende estudantes, entre 6 e 14 anos; isto é, crianças e adolescentes 
Rev. Interd. em Cult. e Soc. (RICS), São Luís, v. 7, n. 1, p. 127 - 147, jan./jun. 2021 ISSN eletrônico: 2447-6498

que "[...] passam por uma série de mudanças relacionadas a aspectos físicos, cognitivos, afetivos, sociais, emocionais, entre outros" (BRASIL, 2017, p. 57).

Além disso, as Diretrizes Curriculares Nacionais Gerais para a Educação Básica (Resolução CNE/CEB $n^{\circ}$ 04/2010) e as Diretrizes Curriculares Nacionais para o Ensino Fundamental de Nove Anos (Resolução CNE/CEB $n^{\circ}$ 07/2010), tal como a Base Nacional Comum Curricular, estabelecem que o Ensino Religioso é uma das cinco áreas de conhecimento e, por consequência, um dos componentes curriculares de oferta obrigatória do Ensino Fundamental.

A Base Nacional Comum Curricular indica ainda que a natureza e as finalidades pedagógicas do Ensino Religioso devem ser “[...] distintas da confessionalidade; pois, buscase 'construir, por meio do estudo dos conhecimentos religiosos e das filosofias de vida, atitudes de reconhecimento e respeito às alteridades"” (BRASIL, 2017, p. 437). Em consonância, o Documento Curricular do Território Maranhense destaca que:

[...] o Ensino Religioso deve ser trabalhado numa perspectiva crítica e democrática, considerando os pressupostos científicos, filosóficos, estéticos e éticos, englobando assim as diferentes manifestações religiosas e filosofias de vida em diferentes tempos e lugares. (BRASIL, 2019, p. 470).

Esses dois documentos normativos recomendam que o Ensino Religioso, no Ensino Fundamental, basicamente, trate da diversidade religiosa brasileira em suas diferentes expressões, sem priorizar, nem menosprezar, nenhuma crença (ou descrença), e que problematize os discursos e as práticas de intolerância religiosa. Isso, seguramente, desafia o Ensino Religioso, pois deve-se mostrar como relevante "[...] na superação de preconceitos, no tratamento adequado às culturas e grupos religiosos silenciados, invisibilizados, negados e/ou exotizados, ao propor o (re)conhecimento do diferente e suas diferenças a partir de, com e em relações alteritárias" (POZZER, 2010, p. 84).

É dentro dessa temática sobre o Ensino Religioso, área do conhecimento e componente curricular do Ensino Fundamental, que este estudo deteve a atenção por meio da análise dos dados coletados com os professores de uma escola pública municipal em Pinheiro.

\section{A obrigatoriedade do Ensino Religioso na escola pública municipal}

Na EPMP, em concordância com a Lei de Diretrizes e Bases e a Base Nacional Comum Curricular, as matrículas são automáticas no Ensino Religioso e, consequentemente, 
Rev. Interd. em Cult. e Soc. (RICS), São Luís, v. 7, n. 1, p. 127 - 147, jan./jun. 2021 ISSN eletrônico: 2447-6498

as aulas constituem-se como obrigatórias para os alunos, sendo literalmente "parte integrante da formação básica" deles. As aulas ocorrem em "horários normais", uma vez que o Ensino Religioso consta no currículo da base nacional comum do Ensino Fundamental, tal como Língua Portuguesa, Matemática, História, Geografia, etc. Inclusive, o Professor E, católico e atual diretor, relatou que os estudantes "não têm conhecimento [do caráter facultativo do Ensino Religioso]. Se tivessem talvez nem participassem [das aulas]". 3

Com o depoimento do Professor E, depreende-se que a conduta da direção e dos professores da EPMP, de não informar e discutir com os estudantes, pais ou responsáveis, fere os princípios da Constituição Federal de 1988 e da Lei de Diretrizes e Bases. Essas leis definem que o Ensino Religioso deve ser com matrícula facultativa nas escolas públicas de Ensino Fundamental, não uma imposição; isto é, apesar da oferta do Ensino Religioso ser obrigatória, a participação dos alunos é opcional.

Não há dúvidas que os professores da EPMP são favoráveis à obrigatoriedade do Ensino Religioso nos currículos das escolas públicas. Essa opinião comprova-se no argumento do Professor B, evangélico, quando explicou que os alunos precisam "de uma religião", de "uma fé maior" e de "um preparo espiritual" no dia a dia e, para tanto, as aulas ministradas teriam que ser "de forma leve, nada com muita pressão", porque "há alunos que respeitam e gostam, que é trabalhado na família, na igreja, etc., mas têm casas de crianças que [a religião] não é muito considerada, que não dão muito apreço. No entanto, eu penso que é necessário incentivar o indivíduo numa religião, seja ela qual for". 4

Essa explicação se estende e, também, condensa as respostas dos outros entrevistados, de entenderem que as aulas de Ensino Religioso devem incentivar os alunos, fazendo com que eles pertençam a uma determinada religião ou, ainda, tornar mais intensa as pertenças religiosas motivadas pela família ou não. Isso se mostra de maneira clara neste relato do Professor C, católico, quando afirma que "precisamos primeiramente de Deus. Atualmente, o nosso Deus está sendo esquecido. Então, temos que inserir nas escolas porque a família está esquecendo e também sendo esquecida. Muitas vezes, nós, a escola, temos que ter essa responsabilidade. ${ }^{5}$ E mais,

As crianças do Ensino Fundamental, Anos Iniciais, chegam à escola e não têm nenhum conhecimento [de religião], se dizem católicos, mas não têm conhecimento

\footnotetext{
${ }^{3}$ E, Professor. Entrevista concedida à Jacimara S. Abreu. Pinheiro, 26 maio de 2020.

${ }^{4} \mathrm{~B}$, Professor. Entrevista concedida à Jacimara S. Abreu. Pinheiro, 24 maio de 2020.

${ }^{5} \mathrm{C}$, Professor. Entrevista concedida à Jacimara S. Abreu. Pinheiro, 27 maio de 2020.
} 
Rev. Interd. em Cult. e Soc. (RICS), São Luís, v. 7, n. 1, p. 127 - 147, jan./jun. 2021 ISSN eletrônico: 2447-6498

específico de nada. É a partir daí que entra a escola, para ensinar as orações diárias, acreditar e ter fé, que cada dia está se perdendo. (grifo nosso). ${ }^{6}$.

Observa-se que as falas dos Professores B e C se complementam em vários aspectos, quando enfatizam o ceticismo, a descrença e a indiferença dos indivíduos em relação à religião, ou ressaltam que os alunos precisam duma religião, que as famílias não instruem os filhos numa religião e de pensarem que a escola tem a "responsabilidade" de exercer influência nas escolhas religiosas das crianças e dos adolescentes. Outro ponto citado pelo Professor C que se relaciona à chamada "família tradicional”, ou "nuclear", que, segundo ela, "está sendo esquecida"; isto é, sofreu várias modificações com o advento da sociedade moderna, onde passou a existir várias configurações de famílias. Esses novos modelos são entendidos como "famílias desestruturadas", sem base para educar os filhos.

Nessa perspectiva, o Professor F, católico, retoma aspectos mencionados pelo Professor $\mathrm{C}$ e acrescenta outros, defendendo que concorda com a obrigatoriedade do Ensino Religioso em razão de:

Ajudar na educação que, hoje em dia, está muito diversificada, filho criado com avó, com tio... Então, quando chega à escola, temos alunos educados de várias maneiras, e com a religião na escola vai ajudar e completar essa educação. (...). Muitas vezes, temos certas famílias que não são estruturadas para trabalhar o caráter do cidadão, a base inicial ali, e a educação religiosa na escola trabalha o que deveria iniciar na família. (grifo nosso). ${ }^{7}$

Como se observa, a partir dos depoimentos dos professores, as justificativas não divergem entre si e convergem para um mesmo posicionamento: o Ensino Religioso na escola seria uma forma de preencher uma falta de crença, uma ausência de incentivo numa religião dos familiares e, ainda, retomar a presença da religião nas salas de aulas num "mundo desencantado", , como o atual. Longe de terem um posicionamento laico, os argumentos dos professores demonstram a "categoria" de ensino na EPMP, sobressaindo elementos de um ensino confessional, em que crianças e adolescentes são instruídos e internalizam preceitos de religiões específicas que os professores acham adequadas para segui-las. A obrigatoriedade do Ensino Religioso funciona como uma espécie de catequese, doutrinação e proselitismo, de modo a fazer "[os alunos] procurarem ir para igreja" 9 .

\footnotetext{
${ }^{6}$ E, op. cit.

${ }^{7}$ F, Professor. Entrevista concedida à Jacimara S. Abreu. Pinheiro, 27 maio de 2020.

${ }^{8}$ A expressão "mundo desencantado" é utilizada por Prandi (1999, p. 63).

${ }^{9}$ E, op. cit.
} 
Rev. Interd. em Cult. e Soc. (RICS), São Luís, v. 7, n. 1, p. 127 - 147, jan./jun. 2021 ISSN eletrônico: 2447-6498

Pode-se afirmar que a oferta do Ensino Religioso na EPMP, na maior parte da visão dos professores, tem o intuito de tornar a escola uma extensão das igrejas, reproduzir seus princípios e conteúdo das religiões a que pertencem. Eles não asseguram o respeito à diversidade religiosa brasileira e não impedem "quaisquer formas de proselitismo", como sugere a Lei de Diretrizes e Bases.

Além disso, as aulas desse componente curricular, na concepção dos professores, são fundamentais "para abrandar as crianças e adolescentes..." religiosa é mais importante [da grade curricular], porque nós vamos nutrir alguns valores essenciais para a convivência humana"11, tal como trabalhar a "formação do caráter do aluno"12. O Ensino Religioso nas salas de aulas é entendido como um "fornecedor de soluções", em que os professores parecem conseguir resolver ou amenizar os problemas de indisciplinas, "rebeldias" dos alunos, etc. Em nenhum momento, eles não conseguem perceber que a moral laica, mais adequada à escola na modernidade, tem justamente esses mesmos objetivos que identificam no Ensino Religioso.

Na coleta de dados, o único depoimento divergente dos entrevistados foi do Professor H, católico, que tem uma concepção destoante dos demais. Sua explicação, apesar de longa, oferece questões interessantes para reconsiderar a presença e obrigatoriedade do Ensino Religioso nas escolas públicas. Além de tudo, mostra problemas que não foram destacados pelos outros professores, quando afirma que:

A religião é uma coisa íntima. Uma coisa muito delicada, porque fica muito difícil para nós impor certa condição numa sala de aula, uma vez que tem professora de uma religião ' $\mathrm{X}$ ', alunos com religião ' $\mathrm{Y}$ '. Então, as pessoas têm que escolher livremente e seguir da melhor maneira a religião que quer seguir sem influências de terceiros. (...). Aí entra aquela questão, a confusão do professor ser doutrinador em escolas públicas, porque se o professor é evangélico, católico, macumbeiro (sic), seja lá o que ele for, ele vai ter uma tendência a puxar mais para a religião dele, e aí, vai acabar discriminando as outras, dizer que as outras não são boas o suficiente (...). Então, penso que seria melhor não ter, que não deveria nem existir na grade curricular. Isso aí ficaria a cargo da instituição família, das instituições religiosas, essas que vão passar o melhor ensinamento, e da livre e espontânea vontade das pessoas escolherem a religião que elas querem. (...). Quando coloca essa questão de obrigatoriedade nas escolas você acaba criando um terreno um pouco conflituoso e extremista. (...) (grifo nosso) ${ }^{13}$.

\footnotetext{
${ }^{10}$ E, op. cit.

${ }^{11} \mathrm{~J}$, Professor. Entrevista concedida à Jacimara S. Abreu. Pinheiro, 25 maio de 2020.

${ }^{12}$ K, Professor. Entrevista concedida à Jacimara S. Abreu. Pinheiro, 30 maio de 2020.

${ }^{13}$ H, op. cit.
} 
Rev. Interd. em Cult. e Soc. (RICS), São Luís, v. 7, n. 1, p. 127 - 147, jan./jun. 2021 ISSN eletrônico: 2447-6498

Nessa fala, alguns pontos merecem ser ressaltados: a religião deveria ser ensinada pela família e pela igreja; o direito à liberdade de crença ou descrença dos indivíduos; a influência que professores exercem; e a questão da intolerância religiosa. Outro problema levantando pelo Professor $\mathrm{H}$ tem relação com o fato da "maioria dos professores que leciona Ensino Religioso não ter formação suficiente e não está preparada para exercer a função. (...). Então, é um tapar o sol com a peneira". ${ }^{14}$

Esse discurso do Professor H é respaldado pelos dados obtidos pela pesquisa, os quais revelaram que os professores que atuam no Ensino Religioso não eram licenciados na área e cumpriam funções fora de suas formações acadêmicas. De igual modo, a ausência de cursos de formação continuada em Ensino Religioso ou de orientações da direção/coordenação, segundo os relatos, "é uma falha que tem na educação", tanto que "só mandavam preparar tudo" ${ }^{16}$, "só direcionam as disciplinas para trabalharmos [durante o ano letivo] e íamos buscando formas e meios de ter acesso" ${ }^{17}$. Além de que os professores "procurava[m] trabalhar, procurava[m] mecanismos para desenvolver o trabalho" ${ }^{18}$, sendo que as aulas eram preparadas com assuntos e conteúdos pesquisados "por conta própria"19. Outras vezes, adquirido "apenas pela igreja" 20 , "em outras instituições"21 ou "com alguns colegas que já trabalhavam com religião, que tinha conhecimento" ${ }^{, 22}$.

Na realidade, a EPMP, segundo os professores entrevistados, não possui nenhum material didático-pedagógico de Ensino Religioso adotado. A seleção e escolha dos conteúdos trabalhados, durante o ano letivo, fica a critério de cada um dos professores responsáveis pelo componente curricular. Eles têm a oportunidade de ensinar os assuntos e adotar os materiais que acreditam serem necessários para a formação dos alunos, durante o Ensino Fundamental.

Mas, voltando à questão da obrigatoriedade, segundo os professores, o Ensino Religioso torna-se muito importante na formação dos alunos enquanto cidadãos, porque trabalha questões fundamentais na formação do caráter do aluno. Eis os relatos:

— Ajuda a desenvolver a questão da ética e dos valores. ${ }^{23}$.

\footnotetext{
${ }^{14} \mathrm{H}$, op. cit.

${ }^{15}$ G, Professor. Entrevista concedida à Jacimara S. Abreu. Pinheiro, 27 maio de 2020.

${ }^{16}$ D, Professor. Entrevista concedida à Jacimara S. Abreu. Pinheiro, 28 maio de 2020.

${ }^{17} \mathrm{~B}$, op. cit.

${ }^{18}$ H, op. cit

${ }^{19}$ I, Professor. Entrevista concedida à Jacimara S. Abreu. Pinheiro, 28 maio de 2020.

${ }^{20} \mathrm{~F}$, op. cit.

${ }^{21} \mathrm{~J}$, op. cit.

${ }^{22}$ E, op. cit.

${ }^{23}$ A, Professor. Entrevista concedida à Jacimara S. Abreu. Pinheiro, 27 maio de 2020.
} 
Rev. Interd. em Cult. e Soc. (RICS), São Luís, v. 7, n. 1, p. 127 - 147, jan./jun. 2021

ISSN eletrônico: 2447-6498

- É benéfico na área espiritual, na questão dos valores, dar valor à vida, amar e respeitar o próximo, que sabemos que hoje é difícil, principalmente nós que somos professores. Nossos alunos não querem mais respeitar os professores. ${ }^{24}$

- Leva aos alunos práticas construtivas e de boa conduta. ${ }^{25}$

- Desenvolve a questão dos valores que eles não têm: laços de cooperação, de responsabilidade, de solidariedade... ${ }^{26}$

- Traz muito benefício. Eles mudam de comportamento, aprendem a respeitar... ${ }^{27}$

As posições dos professores, de que a presença do Ensino Religioso na escola pública ajuda na construção de valores morais dos alunos, não deixam de ser questionáveis, uma vez que, com seus depoimentos, sugerem que somente através dos ensinamentos religiosos as pessoas teriam uma "formação moral" adequada. Sobre isso, Cunha (2013) comenta que:

O ensino de valores éticos, como respeito aos outros e solidariedade, é algo fundamental, que deve permear todo o currículo escolar. Esse tema, no entanto, não pode estar atrelado a uma ou outra crença. Quando isso acontece, passa-se a ideia equivocada de que só religiosos têm valores. Isso é absurdo. Pessoas éticas existem entre religiosos e não religiosos. (CUNHA, $2013^{28}$, grifo nosso).

Assim, a partir dos relatos dos professores, constata-se que uma formação adequada na escola pública está atrelada com o fato dos alunos terem aulas de Ensino Religioso e o componente curricular fazer parte da grade curricular. Em praticamente todos os relatos, os professores reiteraram os aspectos positivos na conduta dos alunos, que participam de forma obrigatória das aulas, por desconhecerem o seu caráter facultativo.

\section{A situação do Ensino Religioso na grade curricular}

A maior parte dos professores pesquisados lecionou no componente curricular Ensino Religioso no Ensino Fundamental; dos entrevistados, somente um não lecionou. Contudo, os depoimentos evidenciaram que não há critérios pedagógicos para que se ministrem aulas de Ensino Religioso, visto que os professores com ou sem formação na área de religião foram responsáveis pelas aulas desse componente curricular.

De acordo com os relatos, as aulas de Ensino Religioso são usadas para complementar a carga horária de outras disciplinas trabalhadas pelos professores efetivos; o Ensino

\footnotetext{
${ }^{24}$ C, op. cit.

${ }^{25} \mathrm{~K}$, op. cit.

26 J, op. cit.

${ }^{27}$ E, op. cit.

${ }^{28}$ Disponível em: https://novaescola.org.br/conteudo/2852/a-escola-publica-nao-pode-ser-uma-arena-dedisputas-religiosas-diz-luiz-antonio-cunha. Acesso em: 15 mar. 2019.
} 
Rev. Interd. em Cult. e Soc. (RICS), São Luís, v. 7, n. 1, p. 127 - 147, jan./jun. 2021 ISSN eletrônico: 2447-6498

Religioso é um componente curricular "geralmente" direcionado pela direção e coordenação aos professores contratados; e pela falta e necessidade de professores com formação na área de Ensino Religioso.

Vale destacar que, frequentemente, os professores contratados suprem a necessidade de disciplinas fora de suas formações. Na rede escolar de Pinheiro, conforme os dados da pesquisa, um professor nessa condição empregatícia dificilmente atua na área de formação, na área que é licenciado. O procedimento, muitas vezes, permite os professores efetivos escolherem suas disciplinas e a secretaria determina que lecione em áreas afins à formação para completar a carga horária e com disciplinas que tenham "afinidade pessoal".

Em razão disso, os dados revelaram ainda que foram as pertenças religiosas dos professores que contribuíram e influenciaram na preparação e ministração de aulas. Vejamos, nas próprias palavras dos entrevistados, o que colaborou na organização das aulas:

— Foi minha formação pessoal, (...). Sou católica, (...). Fui criada nos princípios católicos. $^{29}$

- Eu já tinha a prática de ministrar aula de Ensino Religioso, e sempre tenho formação por parte da Igreja [Católica], que se diferencia da escola. ${ }^{30}$.

- Sou católico; aprendi muito com os catequistas, com os padres, com os legionários... ${ }^{31}$.

— O fato de eu ser uma católica praticante e trabalhar como catequista na Igreja. ${ }^{32}$

Na concepção dos professores, a carga horária de Ensino Religioso deveria ser aumentada, isto é, ter duas aulas por semana como os demais componentes curriculares obrigatórios do Ensino Fundamental, pois, é uma "educação 'do bem",33 e "uma educação diferenciada" 34 . Por ser um componente curricular "diferente" dos outros, por seu caráter religioso, os professores entendem que não é "valorizado" e visto como "fundamental" na formação dos alunos. Isso é ratificado nas seguintes falas:

- Deve-se ter um olhar voltado para a disciplina religião e não deixar que se apague do currículo escolar. (...). Deve ser vista com mais importância, tendo formações e materiais para serem trabalhados. ${ }^{35}$

- Gostaria que o Ensino Religioso fosse visto de uma forma ampla e também com maior importância. (...) Eles colocam o Ensino Religioso, mas não com o intuito de

\footnotetext{
${ }^{29}$ C, op. cit.

${ }^{30} \mathrm{~F}$, op. cit.

${ }^{31}$ E, op. cit.

${ }^{32} \mathrm{D}$, op. cit.

${ }^{33}$ Ibidem.

${ }^{34} \mathrm{~F}$, op. cit.

${ }^{35} \mathrm{~K}$, op. cit.
} 
Rev. Interd. em Cult. e Soc. (RICS), São Luís, v. 7, n. 1, p. 127 - 147, jan./jun. 2021 ISSN eletrônico: 2447-6498

falar de Deus, mas sim falar outras coisas. Penso que há uma grande necessidade de falar mais de Deus nas escolas. ${ }^{36}$

- Era para ser melhor e revisto com carinho, porque cada dia a coisa está piorando. Acredito que, com o tempo, as autoridades vão acabar banindo o Ensino Religioso. ${ }^{37}$ - Ela não é tratada como uma das principais disciplinas da escola, mas deveria ser. Ela não é encarada como uma das mais importantes, apesar de achar a mais importante. ${ }^{38}$

Apesar disso, o Ensino Religioso, na concepção do entrevistado C, "ainda há muito que ser trabalhado para que seja eficiente e abrangente" ${ }^{39}$. As palavras "eficiente" e "abrangente", deixam indícios da falta de um ensino com profissionais qualificados na área de Ensino Religioso que, em suas aulas, abordam a diversidade religiosa, que problematizam e questionam os discursos e as práticas de intolerância religiosa existentes na sociedade.

Ainda sobre a situação do Ensino Religioso na EPMP, o Professor H comenta que:

\begin{abstract}
Eu não a vejo com tanta importância na escola... essa questão religiosa, já temos às duas grandes instituições para dar esse ensinamento, que é a família e a igreja. Penso que essa questão de religião na escola é mais para tornar-se um campo minado e conflituoso, porque temos uma diversidade de religiões em uma sala; e se os alunos já têm certo entendimento, eles não vão aceitar se submeter a determinados colegas que acreditam que a sua religião é melhor. Logo, começa o conflito. Então, penso que a religião fica a cargo das instituições religiosas e da família; essas, entendo que sejam duas bases e que devem tomar conta desse ensinamento. (...). Até porque a escola não é preparada para repassar esse ensinamento adequadamente. (grifo nosso). ${ }^{40}$
\end{abstract}

A fala do Professor H, graduado em Geografia, aponta questões interessantes, pois, segundo ele, o Ensino Religioso é benéfico para o aluno quando tem base na sua família e na instituição religiosa que participa, já que a escola não é preparada para repassar ensinamentos adequados por falta de formação acadêmica dos professores na área de Ensino Religioso.

Por sua parte, o Professor J, além de concordar com a presença do Ensino Religioso na escola pública, demonstra seu descontentamento com a carga horária do componente curricular Ensino Religioso, conforme esse longo depoimento:

Penso que deveria ter mais aulas de religião. Penso que religião era para ser 80 aulas por ano e duas semanais. Era para ser igual História, Inglês, Geografia, duas a duas, entendeu? Acredito ser até uma tentativa de golpear o Ensino Religioso, (...). É a única disciplina que tem 40 horas. Tem só uma aula por semana e que tem 40 aulas anuais. $O$ resto das disciplinas, todas são 80. (...). Uma aula de religião eles usam

\footnotetext{
${ }^{36} \mathrm{G}$, op. cit.

${ }^{37}$ C, op. cit.

${ }^{38}$ J, op. cit.

${ }^{39}$ I, op. cit.

${ }^{40} \mathrm{H}$, op. cit.
} 
Rev. Interd. em Cult. e Soc. (RICS), São Luís, v. 7, n. 1, p. 127 - 147, jan./jun. 2021 ISSN eletrônico: 2447-6498

para complementar a carga horária dos outros [professores], entendeu? Como se fosse um "tapa-buraco". (...). Aí vão fragmentando um pouquinho para cada um. Se fosse duas e duas aulas teriam que contratar ou pegar um professor efetivo para dar aula só de Ensino Religioso, entendeu? (grifo nosso). ${ }^{41}$

Entre os vários aspectos apontados, como o relato do Professor J, destaca-se o fato do Ensino Religioso cumprir uma “função secundária”, já que só tem uma aula por semana e ser distribuída para todo e qualquer professor, independentemente de sua formação. Em outros termos, essa realidade é entendida como uma desvalorização do Ensino Religioso em razão da carga horária anual e semanal ser bastante reduzida e não ter profissionais qualificados na área, quando comparado aos demais componentes curriculares do Ensino Fundamental.

De modo geral, observa-se que as posições dos professores sobre o Ensino Religioso, coloca em dúvida a efetivação da laicidade naquele ambiente escolar. Avalia-se ainda que o caráter "confessional” das aulas de Ensino Religioso na EPMP, visto como positivo pelos professores, é problemático; se for considerado que tal ensinamento deveria ser feito "[...] sob a tutela de autoridades religiosas, [e] só pode[ria] existir custeado pelos fiéis de cada confissão e dentro de seus espaços de culto" (GIUMBELLI, 2004, p. 55) e não em instituições públicas de ensino, como acontece na EPMP, uma escola da rede municipal de Pinheiro, onde se realizou o estudo o presente caso.

\section{Além do Ensino Religioso na escola}

O Ensino Religioso não é a única forma de a religião estar na EPMP, pois, a presença religiosa acontece também "[...] nas práticas cotidianas dos fiéis, o que, de alguma maneira, colabora para que a religião esteja presente nos espaços públicos” (MARTINO, 2016, p. 102). Assim, compreende-se que o fato de os professores terem uma religião faz com que apareça através de seus posicionamentos, suas convivências e seus comportamentos na escola. Nas próprias palavras do Professor $\mathrm{H}$ :

\footnotetext{
A religião está presente nas pessoas, que fazem parte da escola, porque geralmente as pessoas têm uma religião e há uma diversidade de religião dentro dessa comunidade escolar. Então, ela está presente em diferentes maneiras e diferentes olhares, porque o corpo discente, docente e outros funcionários, cada um segue uma religião. Por isso, ela não está presente só na disciplina, mas em todas as pessoas que compõem aquele espaço escolar. (grifo nosso). ${ }^{42}$
}

\footnotetext{
41 J, op. cit.

${ }^{42}$ H, op. cit.
} 
Rev. Interd. em Cult. e Soc. (RICS), São Luís, v. 7, n. 1, p. 127 - 147, jan./jun. 2021 ISSN eletrônico: 2447-6498

Em outros termos, a religião está presente na escola, ainda “[...] através da religiosidade que cada um traz consigo e transparece a todos, mesmo sem falar" ${ }^{23}$. Isso coaduna com Martino (2016), quando ele afirma que:

Quando alguém, em nome da sua fé, adota um estilo de vida, traz voluntária ou involuntariamente essa questão para o espaço público, afinal, a escolha de um modo de vida é também a escolha a respeito de como será a atitude em relação às outras pessoas. (MARTINO, 2016, p. 79).

Além disso, as datas comemorativas cristãs no calendário nacional e local, como os símbolos da Páscoa e do Natal, bem como em Campanha da Fraternidade, Semana Nacional da Família, Ritual da Coroação de Maria e, ainda, comemoração dos "santos padroeiros” da comunidade e da diocese de Pinheiro, que são incorporadas nas práticas pedagógicas, evidenciam a religiosidade dos professores pesquisados.

Todavia, conforme os relatos dos professores, não há presença de crucifixos e imagens católicas na EPMP. Por outro lado, destacaram que:

- A Bíblia é o símbolo mais trabalhado no período das celebrações religiosas, em que eles colocam na escola, como as professoras colocaram lá. A Bíblia ficou aberta o mês de maio todo, (...). ${ }^{44}$.

- Ano passado, eu mesma tive a iniciativa. Fiz um 'cantinho' na escola e coloquei a Bíblia e disse para os alunos que se alguém tivesse interesse, poderia procurar para ler. Teve trechos que tiramos para colocar em momentos de apresentações [de trabalhos]... ${ }^{45}$

Além desses relatos, o Professor E argumenta que, diante da diversidade e das pertenças religiosas dos habitantes da comunidade escolar e local, onde uns são católicos, outros evangélicos, têm-se que:

Procurar uma maneira de colocar um símbolo, vamos dizer assim, para não prejudicar ninguém... O maior símbolo é a Bíblia. Ao invés de colocar outro para desagradar alguém, coloca a Bíblia que agrada todo o mundo, já que têm umas tradições que umas igrejas concordam e outras não. (grifo nosso). ${ }^{46}$

As falas dos Professores (A, E e F) se aproximam, no sentido de enfatizarem a Bíblia como o único símbolo religioso presente na EPMP, pois, segundo eles, representa toda a

\footnotetext{
${ }^{43} \mathrm{~K}$, op. cit.

${ }^{44}$ A, op. cit.

${ }^{45}$ F, op. cit.

${ }^{46}$ E, op. cit.
} 
Rev. Interd. em Cult. e Soc. (RICS), São Luís, v. 7, n. 1, p. 127 - 147, jan./jun. 2021 ISSN eletrônico: 2447-6498

comunidade escolar, bem como é utilizado nas aulas de Ensino Religioso, tendo em vista que a EPMP, não possui nenhum livro "oficial", que seja comum e distribuído aos docentes.

No entanto, nesses relatos, se esqueceram das pessoas que não são cristãs, que não pertencem a nenhum grupo religioso. Noutras palavras, a presença de símbolo religioso na escola pode ser importante para os cristãos, mas, para quem não tem religião, a existência de símbolo pode não fazer sentido e até ser ofensivo.

De todo modo, isso "[...] viola o dispositivo legal de separação Igreja-Estado e franqueia um tratamento desigual entre as religiões, posto que assegura um privilégio para as religiões cristãs, (...)" (ORO, 2011, p. 228). Assim sendo, o fato de ter presença de símbolos cristãos, como a Bíblia, demonstra que não existe diversidade no ambiente escolar.

Ademais, os símbolos religiosos que frequentemente são expostos, na visão do Professor B, "não vem muito influenciar em algo. O símbolo maior que deve ser abordado na escola tem que ser a Bíblia. Ela sendo abordada na escola é de muita utilidade”. Por sua vez, o Professor G considera a presença desses símbolos religiosos é "um desrespeito, porque vem contra a Palavra de Deus, bate muita na questão da idolatria; então, se tenho que respeitar a tua religião, você tem que respeitar minha religião".

As falas dos Professores B e G são problemáticas, no sentido de que um entende que a Bíblia deve ser utilizada como recurso didático no Ensino Fundamental e, o outro, por reproduzir um discurso preconceituoso em relação à Igreja Católica, deixando ver que os conflitos se dão até mesmo entre pessoas cristãs, com posicionamentos diversos ou discordantes.

Outros professores da EPMP argumentam e trazem a questão da laicidade do Estado, para serem favoráveis ou contrários à presença de símbolos religiosos, como pode-se ver:

- Penso que não deveria ter [religião nas escolas], até porque, na própria Constituição [do país], diz que o Estado é laico. Se diz isso, então não tem cabimento dentro de uma instituição pública ter simbologias religiosas puxando um pouco mais sobre determinada religião. ${ }^{47}$

- É complexo de responder. Se o Estado é laico, não deveria ter. (...). Todavia, não tenho nada contra os símbolos. ${ }^{48}$.

- Não me incomoda, apesar de o Estado ser laico, acredito que as pessoas usam mais por costume e fé. ${ }^{49}$.

\footnotetext{
${ }^{47}$ H, op. cit.

${ }^{48} \mathrm{~J}$, op. cit.

${ }^{49}$ I, op. cit.
} 
Rev. Interd. em Cult. e Soc. (RICS), São Luís, v. 7, n. 1, p. 127 - 147, jan./jun. 2021 ISSN eletrônico: 2447-6498

Apesar desses argumentos, coletou-se um depoimento de um professor, que se opõem à questão da laicidade das instituições públicas. Observe-se que:

(...) Os símbolos religiosos, que são as únicas coisas que ainda chamam atenção um pouco quando se olha o símbolo, se diz: aqui é lembrança, é lembrar Jesus crucificado, é lembrar que Jesus morreu por nós. A imagem de Maria Santíssima é lembrar que Maria é a mãe de Jesus, intercede por cada uma de nós. A Bíblia, a palavra de Deus que nos ensina, que nos norteia, têm livros que orientam mesmo dizendo como educar os filhos, como nos relacionarmos uns com os outros. ${ }^{50}$

O Professor deixa claro seu descontentamento com as retiradas de imagens das instituições públicas. Quer dizer, em pleno século XXI, existe uma concepção equivocada de que as aulas de Ensino Religioso sejam para falar das religiões cristãs, que os espaços públicos devem ter presença de símbolos religiosos. Assim, o depoimento do Professor F releva indignação com a laicidade do Estado, já que, pelo menos em "tese”, implicou “[...] a desvinculação entre aparato estatal e instituições religiosas”, bem como "[...] um ideal de eliminação de toda referência a valores e a conteúdos religiosos nas áreas reguladas por leis civis, e, por conseguinte, do próprio espaço público" (GIUMBELLI, 2004, p. 48).

\section{CONSIDERAÇÕES FINAIS}

A partir da pesquisa realizada e das análises feitas, constata-se que as posições dos professores da EPMP sobre o Ensino Religioso não são fundamentadas no princípio da laicidade, da diversidade, da pluralidade de ideias, de opiniões, de crenças. As visões são limitadas e controversas e, ao mesmo tempo, transgridem as leis, as resoluções e os documentos normativos, que fundamentam o Ensino Religioso. Além de que os argumentos e as respostas dos entrevistados, demonstram que a maioria dos professores parece desconhecer o princípio de laicidade que rege o ensino público brasileiro.

Como foi discutido, a maioria dos professores da EPMP que leciona no Ensino Religioso não tem formação adequada, não é licenciada na área. As aulas são organizadas e planejadas a partir das experiências e crenças pessoais, bem como através de informações adquiridas em instituições religiosas cristãs que possuem vínculos. Em outros termos, o fato de não existirem materiais didáticos da área de Ensino Religioso e cursos de formação inicial e continuada, de alguma maneira, interfere nos "modos" dos professores se estruturam e dão

\footnotetext{
${ }^{50}$ F, op. cit.
} 
Rev. Interd. em Cult. e Soc. (RICS), São Luís, v. 7, n. 1, p. 127 - 147, jan./jun. 2021 ISSN eletrônico: 2447-6498

certo "aval" para ensinarem os conteúdos que acreditam serem mais pertinentes para o contexto e realidade dos alunos.

A partir da pesquisa, constatou-se que a presença da religião na escola acontece de forma predominante. Ao que parece, a separação entre Igreja-Estado está longe de ser, de fato, efetivada na EPMP, nas escolas públicas de Pinheiro, e quiçá do país como um todo, visto que várias ações/posições dos professores pesquisados transgrediam as leis, as resoluções e documentos, que regulamentam o ensino público no Brasil.

Por tudo isso, ressalta-se a necessidade de uma prática pedagógica que exige a formação inicial e continuada dos professores da EPMP na área de Ensino Religioso, bem como de uma abordagem dos conteúdos com respeito a diversidade religiosa mediada pelo diálogo inter-religioso. Ademais, sugere-se um estudo mais abrangente das posições dos professores sobre a presença do Ensino Religioso nas escolas públicas do país, uma vez que este estudo, trata apenas de uma realidade particular, isto é, dos professores da EPMP.

\section{REFERÊNCIAS}

BRASIL. Ministério da Educação. Base Nacional Comum Curricular. Brasília, DF, 2017. Disponível em:

http://basenacionalcomum.mec.gov.br/images/BNCC_EI_EF_110518_versaofinal_site.pdf. Acesso em: 12 out. 2019.

Constituição da República Federativa do Brasil de 1988. Brasília, DF:

Presidência da República, 1988. Disponível em:

http://www.planalto.gov.br/ccivil_03/constituicao/constituicao.htm. Acesso em: 21 ago. 2020.

Resolução no 4, de 13 de julho de 2010. Diário Oficial da União, Brasília, 14 de

julho de 2010, Seção 1, p. 824. Disponível em:

http://portal.mec.gov.br/index.php?option=com_docman\&amp;view=download\&amp;alias=5

916-rceb004-10\&amp;category_slug=julho-2010-pdf\&amp;Itemid=30192. Acesso em: 12 mar. 2020.

Resolução no 7, de 14 de dezembro de 2010. Diário Oficial da União, Brasília, 15

de dezembro de 2010, Seção 1, p. 34. Disponível em:

http://portal.mec.gov.br/index.php?option=com_docman\&amp;view=download\&amp;alias=7 246-rceb007-10\&amp;category_slug=dezembro-2010-pdf\&amp;Itemid=30192. Acesso em: 12 mar. 2020.

Documento curricular do território Maranhense: para a Educação Infantil e o Ensino Fundamental. Rio de Janeiro, FGV, 2019.

CAMURÇA, Marcelo Ayres. A questão da laicidade no Brasil: mosaico de configurações e arena de controvérsias. Horizonte, Belo Horizonte, v. 15, n. 47, p. 855-886, jul./set. 2017. 
Rev. Interd. em Cult. e Soc. (RICS), São Luís, v. 7, n. 1, p. 127 - 147, jan./jun. 2021 ISSN eletrônico: 2447-6498

Disponível em: http://periodicos.pucminas.br/index.php/horizonte/article/view/P.21755841.2017v15n47p855/12283. Acesso em: 08 abr. 2019.

CUNHA, Luiz Antonio. "A escola pública não pode ser uma arena de disputas religiosas", diz Luiz Antônio Cunha. Nova Escola, São Paulo, maio, 2013. Disponível em:

https://novaescola.org.br/conteudo/2852/a-escola-publica-nao-pode-ser-uma-arena-dedisputas-religiosas-diz-luiz-antonio-cunha. Acesso em: 15 mar. 2019.

FONSECA, João José Saraiva da. Metodologia da pesquisa científica. Fortaleza, UECE, 2002.

GIL, Antônio Carlos. Métodos e técnicas de pesquisa social. 6. ed. São Paulo, Atlas, 2008.

GIUMBELLI, Emerson. Símbolos religiosos em controvérsias. São Paulo, Terceiro Nome, 2014.

Religião, Estado, modernidade: notas a propósito de fatos provisórios. Estudos Avançados, São Paulo, n.18, v. 52, 2004. Disponível em: https://www.scielo.br/pdf/ea/v18n52/a05v1852.pdf. Acesso em: 08 maio. 2019.

Ensino Religioso em escolas públicas no Brasil: Notas de pesquisa. Debates do NER. Porto Alegre, v. 2, n. 14, 2008. Disponível em:

https://seer.ufrgs.br/debatesdoner/article/view/7280/4631. Acesso em: 12 out. 2019.

IBGE. Cidades. Pinheiro-MA. Disponível em:

https://cidades.ibge.gov.br/brasil/ma/pinheiro/panorama. Acesso em: 28 dez. 2019.

MARIANO, Ricardo. Laicidade à brasileira: católicos, pentecostais e laicos em disputa na esfera pública. Revista Civitas, Porto Alegre, v. 11, n. 2, p. 238-58 maio/ago. 2011.

Disponível em: revistaseletronicas.pucrs.br. Acesso em: 08 maio. 2019.

MARTINO, Luís Mauro Sá. Mídia, religião e sociedade: das palavras às redes digitais. São Paulo, Paulus, 2016.

ORO, Ari Pedro. A laicidade no Brasil e no Ocidente - Algumas considerações. Civitas, Porto Alegre, v. 11, n. 2, p. 221-237, maio-ago. 2011. Disponível em:

https://revistaseletronicas.pucrs.br/ojs/index.php/civitas/article/view/9646/6746Acesso em: 12 out. 2019.

PRANDI, Reginaldo. A religião do planeta global. In: ORO, Ari Pedro; STEIL, Carlos Alberto (Orgs.). Globalização e Religião. $2^{\text {a }}$ ed. Petrópolis, RJ, 1999. p. 63-70

POZZER, Adecir. Concepção de Ensino Religioso no FONAPER: Trajetórias de um conceito em construção. In: POZZER, Adecir et. al. (Orgs.). Diversidade religiosa e ensino religioso no Brasil: Memórias, propostas e desafios - Obra comemorativa aos 15 anos do FONAPER. São Leopoldo: Nova Harmonia, 2010

SILVEIRA, Denise Tolfo; CÓRDOVA, Fernanda Peixoto. A pesquisa científica. In: GERHARDT, Tatiana Engel; SILVEIRA, Denise Tolfo (Org.). Métodos da pesquisa. Porto Alegre, Editora UFRGS, 2009. 
Rev. Interd. em Cult. e Soc. (RICS), São Luís, v. 7, n. 1, p. 127 - 147, jan./jun. 2021 ISSN eletrônico: 2447-6498

STEIL, Carlos Alberto. Pluralismo, modernidade e tradição. Transformações do campo religioso. Ciencias Sociales y Religión/Ciências Sociais e Religião, Porto Alegre, ano 3, n. 3, p. 115-129, out. 2001. Disponível em: www.seer.ufrgs.br/CienciasSociaiseReligiao/article/download/2172/892. Acesso: 12 out. 2019. 